
RESEARCH AND DEVELOPMENT

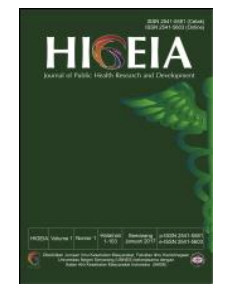

\author{
http://journal.unnes.ac.id/sju/index.php/higeia
}

\title{
Faktor Individual dan Struktural pada Kepuasan Kerja Bidan Era Jaminan Kesehatan Nasional
}

\author{
Amalia Raafiah $\bowtie$
}

Jurusan Ilmu Kesehatan Masyarakat, Fakultas Ilmu Keolahragaan, Universitas Negeri Semarang, Indonesia

\begin{tabular}{l}
\hline Info Artikel \\
\hline Sejarah Artikel: \\
Diterima 18 Juli 2018 \\
Disetujui 19 Oktober \\
2018 \\
Dipublikasikan 30 \\
Oktober 2018 \\
\hline Keywords: \\
Job Satisfaction, Midwife, \\
JKN \\
\hline DOI: \\
https://doi.org/10.15294 \\
/higeia.v2i4.23915
\end{tabular}

/higeia.v2i4.23915

\begin{abstract}
Abstrak
Jaminan Kesehatan Nasional telah berjalan kurang lebih empat tahun, namun Praktik Mandiri Bidan yang bekerjasama dengan BPJS Kesehatan di Kota Semarang mengalami penurunan, pada tahun 2017 sebanyak 95 PMB dan menurun menjadi 85 PMB di tahun 2018. Tujuan penelitian ini adalah untuk mengetahui faktor individual dan struktural pada kepuasan kerja bidan era Jaminan Kesehatan Nasional. Penelitian ini dilaksanakan pada bulan Mei s.d. Juli tahun 2018 di Kecamatan Ngaliyan, Kota Semarang, jenis penelitian ini adalah deskriptif kualitatif dengan pendekatan studi kasus dan teknik pengambilan data menggunakan teknik wawancara mendalam. Informan dalam penelitian ini berjumlah 7 orang dengan 4 orang informan utama dan 3 orang informan triangulasi. Instrumen yang digunakan diantaranya panduan wawancara mendalam, alat perekam dan buku catatan. Data dianalisis menggunakan metode perbandingan tetap. Hasil menunjukkan bahwa faktor individual pada kepuasan kerja bidan adalah nature of work, pencapaian nilai dan motivasi, sedangkan faktor struktural pada kepuasan kerja bidan adalah supervisi, rekan kerja, komunikasi dan keadilan. Simpulan penelitian ini adalah tingkat kepuasan kerja bidan cukup puas pada era JKN.
\end{abstract}

\begin{abstract}
Jaminan Kesehatan Nasional has been running for at least four years, but Independent Practices Midwife who collaboration with BPJS Kesehatan in Semarang City has declined, from 95 IPM in 2017 to 85 IPM in 2018. The objective of this research was to figure out individual and structural factors of Midwife's job satisfaction in Jaminan Kesehatan Nasional era. This research was occurred on May until July 2018 in Ngaliyan Subdistrict, Semarang City, this research was a case study with descriptive qualitative research using in-depth interview technique. Informants in this study amounted to 7 people with 4 main informants and 3 triangulation informants. The instrument used was an in-depth interview guide, a tape recorder and a notebook. Data were analyzed with constant comparative method. Result showed that individual factors of midwife's job satisfaction were nature of work, value attainment and motivation, and structural factors of midwife's job satisfaction were supervision, co-worker, communication and equity. Conclusion of this research was a phase of midwifes's job satisfaction were enough in JKN era.
\end{abstract}

E-mail: amaliarfh@gmail.com 


\section{PENDAHULUAN}

Kesehatan merupakan kebutuhan dasar setiap orang karena aspek kehidupan berhubungan dengan kesehatan. Sehingga negara mengembangkan Sistem Jaminan Sosial Nasional (SJSN) bagi seluruh rakyat Indonesia. Didukung Permenkes Nomor 71 Tahun 2013 dimana Jaminan Kesehatan Nasional (JKN) mencakup seluruh penduduk Indonesia termasuk penduduk asing yang bekerja paling singkat 6 bulan di Indonesia yang telah membayar iuran (Kemenkes RI, 2013). Berlakunya program JKN, maka jaminan kesehatan seperti Jamkesmas dan Jampersal masuk dalam program JKN. Badan Penyelenggara Jaminan Sosial Kesehatan (BPJS Kesehatan) adalah badan hukum yang dibentuk untuk menyelenggarakan program jaminan kesehatan dan merupakan transformasi dari perusahaan asuransi PT. Askes.

Hingga Januari 2018, Fasilitas Kesehatan Tingkat Pertama yang telah bekerjasama dengan BPJS Kesehatan berjumlah 26.775 fasilitas kesehatan, yang terdiri dari 4.878 Dokter Praktik Perorangan, 1.186 Dokter Praktek Gigi, 19 Rumah Sakit Tipe D, 5.533 Klinik Non Rawat Inap, 312 Klinik Rawat Inap, 7.061 Puskesmas, 2.796 Puskesmas + TT, 215 Klinik Utama, 2.109 Rumah Sakit, 1.043 Optik dan 1.628 Apotek (BPJS Kesehatan, 2018).

Provinsi Jawa Tengah merupakan provinsi dengan tingkat FKTP yang bekerjasama dengan BPJS Kesehatan tertinggi se-Indonesia yaitu sebanyak 2.749 FKTP pada tahun 2016, mengalami kenaikan dari tahun 2015 yaitu 2.656 FKTP. Sebaliknya, Kota Semarang mengalami penurunan FKTP khususnya Dokter Praktik Perorangan (DPP) yaitu sebanyak 68 DPP pada tahun 2018, dari tahun 2017 sebanyak 79 DPP. Hal ini berimbas pada PMB yang berjejaring dengan DPP apabila DPP tersebut sudah tidak bekerjasama lagi dengan BPJS Kesehatan. Pada tahun 2017 sebanyak 95 PMB menurun menjadi $85 \mathrm{PMB}$ pada tahun 2018 (BPJS Kesehatan, 2018). Seperti yang kita ketahui, JKN sudah berjalan kurang lebih empat tahun, sehingga menurunnya PMB jejaring merupakan suatu hal yang dipertanyakan.

Praktik Mandiri Bidan (PMB) merupakan pelayanan kebidanan yang dilakukan oleh bidan secara perorangan. Bidan yang menjalankan praktik keprofesiannya wajib memiliki Surat Izin Praktik Bidan (SIPB). SIPB merupakan bukti tertulis yang diberikan oleh pemerintah daerah kabupaten/kota pada bidan sebagai pemberian kewenangan menjalankan praktik kebidanan.

Menurunnya PMB jejaring dapat disebabkan karena adanya perbedaan biaya pelayanan pada pasien umum dan JKN. Misalnya, pada pelayanan persalinan normal, PMB mematok biaya sebesar Rp 900.000,00 s.d. Rp 1.000.000,00 pada pasien umum, sedangkan pada pasien JKN telah ditetapkan sebesar Rp 700.000,00 berdasarkan Permenkes Nomor 52 Tahun 2016 tentang Standar Tarif Pelayanan Kesehatan dalam Penyelenggaraan Program JKN. Jumlah PMB jejaring yang menurun, menyebabkan banyak peserta yang mengantri dan menumpuk di Puskesmas sehingga mengakibatkan kurang optimalnya sistem pelayanan dan rujukan pada FKTRL (Yandrizal, 2013).

Kesesuaian upah dapat mempengaruhi kepuasan kerja seseorang, kepuasan kerja mempengaruhi kinerja, kinerja mempengaruhi ketercapaian tujuan (Kusuma, 2016), sehingga kepuasan kerja bidan terhadap upah secara individu besar pengaruhnya terhadap kinerja bidan, apabila bidan puas terhadap upah pekerjaannya, ia akan memiliki motivasi untuk mengembangkan dan meningkatkan kualitas pelayanan sehingga kinerja bidan dalam melayani pasien akan meningkat, kinerja bidan yang baik memberikan peluang untuk menurunkan Angka Kematian Ibu.

Dalam studi pendahuluan yang dilakukan oleh peneliti, PMB menerangkan bahwa rendahnya nominal klaim yang didapat oleh PMB dikarenakan pasien JKN menolak untuk melakukan persalinan di bidan dan lebih memilih dirujuk di rumah sakit. Berdasarkan penelitian Kusuma (2016), ketidakpuasan PMB era JKN yaitu pada ketepatan waktu BPJS 
Kesehatan dalam mengganti klaim dimana penggantian klaim melebihi peraturan yang ditetapkan yaitu 15 hari kerja sejak dokumen klaim diterima lengkap, selain itu PMB juga kurang mengerti prosedur penggantian klaim karena kurangnya sosialisasi dari BPJS Kesehatan, menurut Tryanto \& Indrawati (2017) kurangnya sosialisasi menyebabkan kurang pahamnya bidan terhadap prosedur yang mengakibatkan kurangnya motivasi kerja sehingga dapat menimbulkan kinerja SDM yang tidak maksimal.

Kepuasan kerja merupakan dapat diartikan sebagai refleksi dari seberapa jauh seseorang merasa tertarik dan terdorong pada suatu pekerjaan, sehingga pekerjaan tersebut mempunyai nilai tertentu bagi dirinya (Karambut, 2012). Kepuasan kerja menunjukkan hubungan dengan faktor kinerja dan kepuasan kerja merupakan preferensi nilai yang dipegang banyak peneliti perilaku organisasi. Pada umumnya, pekerjaan yang menarik dan menantang serta perkembangan karir merupakan hal yang dapat mempengaruhi kepuasan kerja (Taufiqurrahman, 2014). Indikator dari kepuasan kerja diantaranya adalah upah, keterjaminan pekerjaan, teman kerja, penghargaan, kesempatan berkarir, kepemimpinan yang adil dan organisasi yang relevan (Tumewu, 2014). Apabila pekerja puas, tingkat turnover dan absen akan berkurang (Mukururi, 2014).

Menurut Kreitner dan Kinicki (2013) terdapat lima faktor yang dapat mempengaruhi kepuasan kerja diantaranya (1) Pemenuhan kebutuhan, (2) Ketidaksesuaian, (3) Pencapaian nilai, (4) Keadilan, (5) Komponen genetik. Sedangkan menurut Spector dalam Kusuma, kepuasan kerja memiliki sembilan aspek, diantaranya (1) Jumlah upah, (2) Promosi, (3) Supervisi, (4) Benefit, (5) Contingent rewards, (6) Operating procedures, (7) Rekan kerja, (8) Nature of work, (9) Komunikasi.

Kepuasan dapat berasal dari dirinya sendiri atau faktor individual maupun dukungan dari lingkungannya atau faktor struktural. Faktor individual merupakan hubungan sikap seseorang terhadap pekerjaannya, dalam penelitian ini yang dimaksud dengan faktor individual diantaranya nature of work, pemenuhan kebutuhan, harapan, pencapaian nilai dan motivasi, sedangkan faktor struktural adalah suatu keadaan relatif yang dapat membantu untuk memperoleh hasil seperti kebijakan dari pemerintah dan dukungan sosial, dalam penelitian ini faktor struktural adalah kebijakan yang berlaku, seperti kebijakan upah, supervisi oleh Dinas Kesehatan, IBI maupun BPJS Kesehatan, sistem jejaring, prosedur administrasi penggantian klaim, rekan kerja jejaring, komunikasi dengan jejaring dan keadilan oleh jejaring.

Perbedaan antara penelitian ini dengan penelitian sebelumnya adalah variabel pemenuhan harapan, pencapaian nilai, motivasi dan keadilan yang berpengaruh pada kepuasan kerja Pratik Mandiri Bidan, oleh sebab itu penelitian ini bertujuan untuk mengetahui faktor individual dan faktor struktural yang berhubungan dengan kepuasan kerja praktik mandiri bidan era Jaminan Kesehatan Nasional di Kecamatan Ngaliyan.

\section{METODE}

Jenis penelitian yang digunakan adalah jenis penelitian deskriptif kualitatif. Jenis penelitian kualitatif cocok untuk digunakan dalam penelitian ini, dikarenakan penelitian kualitatif digunakan untuk meneliti sesuatu yang mendalam, untuk menelaah sesuatu yang bersifat latar belakang misalnya motivasi, peranan, sikap, nilai dan persepsi. Penelitian ini menggunakan pendekatan studi kasus dengan tujuan untuk mendeskripsikan konteks dan terjadinya suatu kasus, fokus diarahkan pada pembahasan tentang tema, isu dan implikasi pada suatu kasus (Gumilang, 2016). Paradigma interpretatif, pendekatan fenomenologis dan konstruktif sebagai dasar paradigma penelitian kualitatif terkait erat dengan definisi dan karakteristik studi kasus (Starman, 2013).

Penelitian ini dilaksanakan pada bulan Mei s.d. Juli tahun 2018 di Kecamatan Ngaliyan Kota Semarang dengan sumber informasi berupa sumber primer dan sekunder, 
sumber primer diperoleh dari hasil wawancara mendalam (in depth interview) secara langsung kepada informan kunci atau narasumber utama yang telah dipilih dan bersedia memberikan informasi penelitian. Informan kunci atau narasumber utama dalam penelitian ini adalah Praktik Mandiri Bidan (PMB) yang memiliki jejaring dengan Dokter Praktik Perorangan (DPP) atau Klinik yang bekerjasama dengan BPJS Kesehatan dan bekerja di wilayah Kecamatan Ngaliyan. sedangkan sumber sekunder diperoleh dari data daftar PMB yang bekerjasama dengan BPJS Kesehatan tahun 2017, diambil dari BPJS Kesehatan Kota Semarang dan Ikatan Bidan Indonesia Cabang Kota Semarang. Teknik sampel yang digunakan untuk menemukan informan kunci atau narasumber utama dalam penelitian ini adalah dengan purposive sampling. Apabila dalam proses analisis data peneliti telah menemukan pola yang sama berulang kali, maka analisis sudah dapat dihentikan karena saat itu terjadi kejenuhan data (Zakiah, 2015).

Instrumen dalam penelitian ini adalah peneliti yang berperan sebagai instrumen dan dibantu seorang pendamping yang membantu mencatat dan merekam hasil wawancara mendalam serta dokumentasi. Peneliti menggunakan panduan wawancara (in depth interview) untuk menggali informasi lebih dalam tentang faktor individual dan faktor struktural yang berhubungan dengan kepuasan kerja Praktik Mandiri Bidan era Jaminan Kesehatan Nasional dan instrumen lain yang digunakan berupa alat perekam, buku catatan serta kamera. Teknik pengumpulan data pada penelitian ini menggunakan teknik wawancara mendalam (in depth interview technique). Responden diminta menjawab pertanyaan penelitian sebaik dan sejujur mungkin, dengan pertimbangan agar peneliti bisa lebih akurat dalam memperoleh dan menganalisa suatu data, agar semakin akurat pula hasil penelitiannya (Alshenqeeti, 2014).

Pada penelitian ini, peneliti menggunakan teknik triangulasi sumber untuk memeriksa keabsahan data, teknik triangulasi sumber yaitu membandingkan dan mengecek kembali suatu informasi yang diperoleh melalui waktu dan alat yang berbeda dalam penelitian kualitatif. Hal itu dapat dicapai dengan (1) membandingkan data hasil pengamatan dengan data hasil wawancara; (2) membandingkan apa yang dikatakan orang di depan umum dengan apa yang dikatakan secara pribadi; (3) membandingkan apa yang dikatakan orang tentang situasi penelitian dengan apa yang dikatakan sepanjang waktu; membandingkan keadaan dan perspektif seseorang dengan berbagai pendapat dan pandangan orang seperti rakyat biasa, orang yang berpendidikan menengah atau tinggi, orang berada dan orang pemerintahan; (5) membandingkan hasil wawancara dengan isi suatu dokumen yang berkaitan. Dari kelima teknik triangulasi sumber yang telah diuraikan, peneliti menggunakan teknik nomor 4 yaitu dengan cara membandingkan hasil wawancara narasumber utama dengan narasumber triangulasi. Dalam penelitian ini, narasumber triangulasi diantaranya Dinas Kesehatan Kota Semarang dan Ikatan Bidan Indonesi (IBI) Cabang Semarang guna memberikan informasi mengenai kebijakan JKN yang berlaku dan hubungannya dengan bidan, jejaring FKTP yang bekerjasama dengan BPJS Kesehatan Bidan dan memiliki jejaring Praktik Mandiri Bidan agar memberikan informasi terkait pelaksanaan kerjasama dengan Praktik Mandiri serta BPJS Kesehatan Kota Semarang guna memberikan informasi terkait pelaksanaan JKN di lapangan dari sudut pandang yang berbeda.

Teknik analisis data yang digunakan dalam penelitian ini adalah dengan metode perbandingan tetap. Dinamakan metode perbandingan tetap atau Constant Comparative Method karena dalam analisis data, secara tetap membandingkan satu data dengan data yang lain, kemudian secara tetap membandingkan kategori dengan kategori lainnya.

\section{HASIL DAN PEMBAHASAN}

Penelitian ini dilaksanakan di Kecamatan Ngaliyan, Kota Semarang, dengan iklim tropis dan memiliki dua musim yaitu musim kemarau 
Tabel 1. Karakteristik Informan

\begin{tabular}{ccccc}
\hline $\begin{array}{c}\text { Infor- } \\
\text { man }\end{array}$ & $\begin{array}{c}\text { Umur } \\
\text { (tahun) }\end{array}$ & $\begin{array}{c}\text { Jenis } \\
\text { Kelamin }\end{array}$ & $\begin{array}{c}\text { Pendi- } \\
\text { dikan }\end{array}$ & $\begin{array}{c}\text { Masa } \\
\text { Kerja } \\
\text { (tahun) }\end{array}$ \\
\hline 1 & 64 & Perempuan & D3 & 26 \\
2 & 65 & Perempuan & D3 & 20 \\
3 & 40 & Perempuan & D3 & 5 \\
4 & 65 & Perempuan & D3 & 30 \\
\hline
\end{tabular}

dan penghujan dengan suhu antara $18^{\circ}-33^{\circ} \mathrm{C}$. Kecamatan Ngaliyan memiliki luas daerah $3.181,96$ ha dengan batas wilayah sebelah utara Kecamatan Tugu, sebelah selatan Kecamatan Mijen dan Gunungpati, sebelah barat Kabupaten Kendal dan sebelah timur Kecamatan Semarang Barat dan Gajahmungkur. Kecamatan Ngaliyan memiliki 10 kelurahan, $122 \mathrm{RW}$ dan $86 \mathrm{RT}$, jumlah penduduk 138.347 orang dengan rincian 41.595 KK, 69.146 laki-laki dan 69.201 perempuan dengan kepadatan penduduk $2.173 \mathrm{~km} /$ jiwa. Dalam melayani kesehatan ibu dan anak, Kecamatan Ngaliyan memiliki 15 Praktik Mandiri bidan dengan 10 PMB belum berjejaring dengan FKTP BPJS Kesehatan dan 5 PMB telah berjejaring dengan FKTP BPJS Kesehatan.

Informan utama dalam penelitian ini adalah Praktik Mandiri Bidan yang bekerjasama dengan BPJS Kesehatan dengan berjejaring melalui Dokter Praktik Perorangan (DPP) maupun Klinik Pratama di wilayah Kecamatan Ngaliyan, Kota Semarang.

Penelitian ini menggunakan informan triangulasi sebagai cross check atas fakta-fakta yang diperoleh di lapangan. Informan triangulasi berjumlah empat orang diantaranya
Dinas Kesehatan Kota Semarang, Ikatan Bidan Indonesia Cabang Semarang dan Kepala Klinik yang bekerjasama dengan BPJS Kesehatan dan memiliki jejaring Praktik Mandiri Bidan serta petugas BPJS Kesehatan Kota Semarang.

Nature of work diartikan sebagai pekerjaan yang bisa dinikmati atau tidak oleh pekerja (Spector dalam Kusuma, 2016). Faktor nature of work yang diteliti dalam penelitian ini merupakan persepsi kesenangan, kebanggaan dan rasa sia-sia bidan dalam melayani pasien JKN. Hasil penelitian menunjukkan bahwa seluruh informan merasa senang menjadi bidan yang bisa melayani pasien JKN, namun informan tidak begitu bangga maupun merasa sia-sia dalam melayani pasien JKN. Mengingat bahwa sebagian besar responden (75\%) berusia antara 60-65 tahun dengan usia termuda 40 tahun dan usia tertua 65 tahun. Usia merupakan faktor yang tidak bisa diabaikan karena dapat mempengaruhi kekuatan fisik dan psikis seseorang yang mengalami perubahan usia $>30$ tahun karena merupakan usia yang cukup matang dalam perkembangan jiwa seseorang. Kepuasan kerja meningkat pada usia 30-an, kemudian menurun pada usia 40-an dan akan meningkat lagi pada usia 50-an sampai mereka pensiun (Rindyantika \& Safitri, 2014).

Faktor usia merupakan faktor yang tidak bisa diabaikan, mengingat hal tersebut mempengaruhi kekuatan fisik dan psikis seseorang serta pada usia tertentu seorang pekerja akan mengalami perubahan potensi kerja. Pekerja yang lebih senior cenderung puas dengan pekerjaannya karena mereka lebih mampu menyesuaikan diri dengan lingkungan berdasarkan pengalamnnya. Mereka cenderung

Tabel 2. Karakteristik Informan Triangulasi

\begin{tabular}{|c|c|c|c|c|c|}
\hline Informan & Jabatan & Umur & $\begin{array}{l}\text { Jenis } \\
\text { Kelamin }\end{array}$ & Pendidikan & $\begin{array}{l}\text { Masa } \\
\text { Kerja }\end{array}$ \\
\hline 1 & $\begin{array}{l}\text { Staf Jaminan Kesehatan dan } \\
\text { Kemitraan }\end{array}$ & 44 th & Perempuan & S2 & 10 th \\
\hline 2 & $\begin{array}{l}\text { Ketua Ikatan Bidan Indonesia } \\
\text { Cabang Kota Semarang }\end{array}$ & 63 th & Perempuan & S2 & 10 th \\
\hline 3 & $\begin{array}{l}\text { Pemilik Klinik Kembang Arum } \\
\text { Medika }\end{array}$ & 39 th & Perempuan & S1 & 5 th \\
\hline 4 & Staf Penjaminan Mutu Primer & 26 th & Laki-laki & S1 & 2 th \\
\hline
\end{tabular}


lebih stabil emosinya sehingga secara keseluruhan dapat bekerja lebih teratur dan mantap (Safarah, 2018).

Selain melihat dari faktor usia, masa kerja juga dapat mempengaruhi kepuasan kerja. Masa kerja dapat diartikan dengan pengalaman seseorang selama memberikan pelayanan (Green, 2017). Semakin lama masa bekerja maka semakin banyak pengalaman dan kasus yang ditangani akan membuat seseorang mampu melaksanakan pelayanan dengan baik. Melihat sebagian besar informan (75\%) telah bekerja menjadi PMB selama 20-30 tahun. Apabila masa kerja tinggi, maka kepuasan kerja akan tinggi, sebaliknya apabila masa kerja rendah maka kepuasan kerja akan rendah pula (Safarah, 2018)

Kesempatan untuk memenuhi kebutuhan yang diberikan oleh sebuah pekerjaan mempengaruhi kepuasan kerja seseorang (Kreitner \& Kinicki, 2014). Faktor pemenuhan kebutuhan yang diteliti dalam penelitian ini merupakan tingkatan pemenuhan kebutuhan bidan dari hasil klaim yang didapatkan dalam melayani pasien JKN. Hasil penelitian menunjukkan bahwa seluruh informan (100\%) tidak bisa memenuhi kebutuhannya baik kebutuhan primer, sekunder maupun tersier dari hasil melayani pasien JKN, meskipun hasil klaim yang diajukan tidak bisa untuk memenuhi kebutuhan, PMB masih melayani pasien JKN yang ingin bersalin di bidan, hanya saja sebagian besar pasien JKN lebih memilih bersalin di rumah sakit, mengingat keduanya sama-sama di cover oleh BPJS Kesehatan. Meskipun informan tidak bisa memenuhi kebutuhan dari melayani pasien JKN, informan memenuhi kebutuhan dari melayani pasien umum, pekerjaan lain dan bantuan dari anak atau suami.

Maslow menyebutkan bahwa kebutuhan fisiologis merupakan sekumpulan kebutuhan dasar yang paling mendesak pemenuhannya karena terkait dengan kelangsungan hidup manusia, kebutuhan yang pemenuhannya tidak mungkin ditunda. Apabila seseorang tidak bisa memenuhi kebutuhannya maka akan mempengaruhi kehidupan pribadi tersebut menjadi tidak berkembang atau bahkan mengalami penyimpangan (Hikma, 2015). Menurut Need Fulfillment Theory, kepuasan kerja seseorang bergantung pada terpenuhi atau tidaknya kebutuhannya. Seseorang akan merasa puas apabila ia mendapatkan apa yang dibutuhkannya, semakin besar kebutuhan yang bisa terpenuhi, maka kepuasan kerja semakin tinggi, begitu pula sebaliknya, apabila kebutuhan tidak terpenuhi, maka ia akan merasa tidak puas.

Pemenuhan harapan mencerminkan perbedaan antara apa yang diharapkan dan apa yang diperoleh individu dari pekerjaan. Faktor harapan yang diteliti dalam penelitian ini merupakan harapan bidan sebelum bekerja sebagai bidan jejaring dan sesudah menjadi bidan jejaring. Hasil penelitian menunjukkan bahwa sebagian besar (75\%) informan mengatakan bahwa mereka tidak mencapai harapan mereka sebelum bekerja menjadi bidan jejaring. Melihat dari harapan bidan sebelum menjadi bidan jejaring, bidan mengharapkan adanya tambahan pasien sehingga meningkatkan penghasilan dari hasil klaim yang dibayarkan oleh BPJS Kesehatan, namun faktanya pasien JKN cenderung memilih bersalin di rumah sakit dibanding bersalin di bidan, tentunya hal ini tidak sesuai dengan apa yang diharapkan bidan sebelum menjadi bidan jejaring. Tidak tercapainya harapan bidan menyebabkan ketidakpuasan kerja, hal ini sesuai dengan pernyataan Kreitner \& Kinicki (2014), apabila harapan lebih besar daripada yang diterima, orang akan tidak puas, sebaliknya diperkirakan individu akan puas apabila mereka menerima manfaat di atas harapan.

Tidak terpenuhinya harapan PMB disebabkan karena kurangnya promosi dan motivasi dari bidan kepada pasien JKN untuk bersalin di bidan, giatnya promosi yang disampaikan rumah sakit baik secara langsung maupun dari rekomendasi sesama pasien, menyebabkan pasien mulai beralih ke rumah sakit karena peralatan yang dimiliki rumah sakit lebih lengkap dibanding bidan apabila persalinan tidak bisa normal. Hal ini sejalan 
dengan penelitian Čiarnienè, dimana tidak tercapainya harapan dapat dikarenakan kurangnya usaha, pelaksanaan, penghargaan dan motivasi untuk mewujudkan harapan yang dibangun (Čiarnienè , 2010).

Gagasan pencapaian nilai adalah kepuasan merupakan hasil dari persepsi pekerjaan yang memberikan pemenuhan nilai kerja individual. Faktor pencapaian nilai yang diteliti dalam penelitian ini adalah kebanggaan bidan terhadap pekerjaannya saat ini dan pemenuhan tanggung jawab bidan terhadap pekerjaannya. Hasil penelitian menunjukkan bahwa sebagian besar bidan (75\%) bangga terhadap pekerjaannya, dan memenuhi tanggung jawabnya sebagai bidan jejaring. Hal tersebut mendukung teori Model Theory of Work Adjustment, kondisi yang penting dan penguat dalam menciptakan kepuasan kerja salah satunya adalah faktor tanggung jawab.

Dalam penelitian Kusuma (2016), diterangkan bahwa PMB yang mencapai tingkat kepuasan merupakan $\mathrm{PMB}$ yang bertanggung jawab pada pasiennya, PMB rela mendatangi rumah pasien JKN untuk melakukan pemeriksaan KF1 dan KF2, meskipun penggantian klaim terpotong oleh biaya akomodasi.

Motivasi merupakan suatu produk dari bagaimana seseorang menginginkan sesuatu dan penaksiran seseorang memungkinkan aksi tertentu yang akan menuntunnya. Faktor motivasi yang diteliti dalam penelitian ini adalah motivasi bidan untuk ikut berjejaring dan motivasi bidan untuk mempromosikan JKN. Hasil penelitian menunjukkan bahwa seluruh informan $(100 \%)$ mendapat motivasi untuk ikut berjejaring dari ajakan pihak luar, baik dokter atau teman kerja dan seluruh informan $(100 \%)$ termotivasi dari dirinya sendiri untuk mempromosikan JKN baik kepada pasien, tetangga maupun keluarga.

Motivasi dapat diartikan kekuatan atau energi seseorang yang dapat menimbulkan tingkat persistensi dan entusiasmenya dalam elaksanakan suatu kegiatan, baik yang bersumber dari dalam individu itu sendiri (intrinsik) maupun dari luar individu (ekstrinsik). Seberapa kuat motivasi yang dimiliki individu akan banyak menentukan terhadap kualitas perilaku yang ditampilkannya, baik dalam konteks belajar, bekerja maupun kehidupan lainnya. Menurut teori Mc Clelland tentang teori kebutuhan untuk mencapai prestasi (need for achievement) menyatakan bahwa motivasi berbeda-beda sesuai dengan kebutuhan seseorang akan prestasi (Kreitner \& Kinicki, 2014).

Berdasarkan hasil penelitian Kadek (2015), motivasi berpengaruh positif dan signifikan terhadap kinerja pegawai, diketahui bahwa motivasi PMB dalam berjejaring adalah adanya faktor kebutuhan aktualisasi diri sebagai bentuk pengabdian PMB kepada masyarakat dan kepatuhan terhadap aturan pemerintah. Pengaruh motivasi kerja, kepemimpinan dan budaya organisasi terhadap kepuasan kerja karyawan serta dampaknya pada kinerja perusahaan, membuktikan bahwa motivasi kerja berpengaruh positif dan signifikan terhadap kepuasan kerja karyawan. Kepuasan erja akan tercapai bila seorang pekerja memiliki kepuasan dari dalam dirinya sendiri untuk melakukan pekerjaannya (Saleem, 2010).

Gaji atau upah merupakan imbalan jasa atau uang yang dibayarkan atau ditentukan untuk dibayarkan kepada seseorang pada jarak waktu yang teratur untuk jasa yang diberikan (Spector dalam Kusuma , 2016). Faktor upah yang diteliti dalam penelitian ini adalah penggantian klaim yang wajar oleh BPJS Kesehatan kepada PMB. Hasil penelitian menunjukkan bahwa seluruh informan (100\%) mengatakan bahwa klaim yang dibayarkan tidak setara dengan pekerjaan yang telah dilakukan bidan dan ada ketidaksesuaian besarnya tarif di pasaran umum terutama pada pelayanan $\mathrm{KB}$ dan persalinan. Selain itu, ada pula keluhan dari bidan bahwa apabila ada kesalahan dalam pengajuan klaim, BPJS Kesehatan secara otomatis tidak mengganti klaim, tanpa mengkomunikasikan dengan PMB terlebih dahulu.

Hasil yang sama juga ditunjukkan pada penelitian yang dilakukan Kusuma (2016), dimana penggantian tarif klaim ANC 
dikeluhkan yang hanya dapat dilakukan sebanyak 4 kali terlebih dahulu untuk dianggap satu rangkaian klaim dan penggantiannya dilakukan bersamaan dengan penggantian klaim persalinan sehingga harus menunggu hingga pasien melahirkan di tempat praktik bidan untuk dapat diajukan klaimnya atas pelayanan ANC yang diberikan. Selain itu, ketika PMB menerima pasien persalinan di tempat praktiknya, akan ada biaya rawat inap sekaligus dengan konsumsi untuk pihak pasien yang hendak melahirkan maupun untuk keluarga yang menunggu. Selain itu pemberian infus dan obat juga dilakukan selama pasien melakukan persalinan. Sedangkan untuk pelayanan KB sebenarnya pengadaan alat kontrasepsi merupakan tanggung jawab BKKBN, PMB yang menjadi jejaring dapat memanfaatkan fasilitas tersebut dengan melakukan registrasi ke SIM BKKBN melalui pendaftaran faskes $\mathrm{KB}$, jadi biaya hasil klaim dari BPJS Kesehatan merupakan jasa medis yang diberikan. Oleh karena kurang pahamnya PMB mengenai kebijakan tersebut merupakan penggantian klaim dengan pengadaan alat kontrasepsi $\mathrm{KB}$ secara pribadi (Kusuma, 2016). Kebijakan penggantian klaim secara parsial berpengaruh positif dan signifikan terhadap kepuasan kerja, loyalitas dan semangat kerja banyak dipengaruhi oleh kompensasi (Suyasa, 2016).

Supervisi merupakan kegiatan pengarahan serta pengendalian pekerja dalam suatu organisasi. Faktor supervisi yang diteliti dalam penelitian ini adalah dukungan dari pemerintah dan organisasi profesi terhadap bidan jejaring serta pengawasan dari jejaring kepada bidan. Hasil penelitian menunjukkan bahwa sebagian (50\%) bidan mengatakan tidak pernah ada sosialisasi JKN kepada bidan, dan sebagian $(50 \%)$ bidan mengatakan pernah ada sosialisasi JKN kepada bidan. Dari Dinas Kesehatan Kota Semarang menerangkan bahwa sosialisasi tidak diadakan secara khusus kepada bidan, melainkan kepada masyarakat umum dan beberapa tenaga kesehatan, sosialisasi kepada bidan biasanya diadakan oleh IBI yang bekerjasama dengan BPJS Kesehatan dan dilakukan saat pertemuan rutin IBI berlangsung.
Kurangnya sosialisasi tentang program JKN yang diberikan kepada PMB akan sangat mempengaruhi pengetahuan bidan tentang program JKN. Program JKN ditunjukan untuk meningkatkan derajat kesehatan dalam hal ini bidan membantu pemerintah menurunkan AKI dan AKB. Bidan sebagai ujung tombak merupakan tenaga kesehatan yang paling terdepan melayani masyarakat terutama untuk meningkatkan kesehatan ibu dan anak di Indonesia (Zakiah, 2015).

Hasil penelitian terkait dukungan terhadap bidan untuk menjadi bidan jejaring menunjukkan bahwa seluruh informan (100\%) mengatakan bahwa mereka tidak dipaksa untuk menjadi bidan jejaring, hanya ada dukungan khusus dari jejaring berupa ajakan kepada bidan untuk menjadi bidan jejaring, bergabungnya PMB menjadi bidan jejaring berdasarkan ajakan jejaringnya maupun usaha dan kemauan tiap individu bidan. Dukungan dari Dinas Kesehatan, IBI maupun BPJS Kesehatan sebenarnya sangat berpengaruh pada kepuasan PMB, hal yang sama juga disampaikan oleh Adolfina (2014) bahwa dalam lingkungan kerja ada beberapa aspek yang memberikan kepuasan, diantaranya promosi, rekan kerja dan supervisi, dimana supervisi merupakan kemampuan penyelia untuk memberikan bantuan teknis dan dukungan perilaku.

Hasil penelitian terkait supervisi jejaring kepada bidan, menunjukkan bahwa sebagian besar $(75 \%)$ bidan mengatakan bahwa ada pengawasan oleh jejaringnya terhadap pekerjaannya. Penelitian Bakotić \& Babić (2013) menerangkan bahwa meningkatkan kondisi pekerjaan dari segi keselamatan, pengarahan, kontrol dan pengawasan dapat meningkatkan kepuasan kerja seseorang, karena kondisi pekerjaan yang nyaman meningkatkan kepuasan yang berpengaruh pada kinerja seseorang.

Prosedur adalah suatu instruksi (perintah kerja) yang terperinci dan tertulis yang harus diikuti untuk menjalankan suatu pekerjaan tertentu. Faktor prosedur yang diteliti dalam penelitian ini adalah kenyamanan dan kemudahan pekerjaan karena prosedur yang 
dijalankan. Hasil penelitian menunjukkan bahwa sebagian (50\%) tidak setuju adanya sistem jejaring karena tahapan yang dilalui pasien untuk rujuk cukup banyak, sedangkan untuk penggantian klaim sebagian besar (75\%) bidan mengajukan melalui jejaring, meskipun hasil klaim langsung dikirim ke rekening bidan, sebagian besar (75\%) bidan merasa BPJS Kesehatan tidak tepat waktu dalam mengganti klaim.

Adanya sistem jejaring atau gatekeeper concept diterapkan agar Fasilitas Kesehatan Tingkat Pertama yang berperan sebagai pemberi pelayanan kesehatan dasar berfungsi optimal sesuai standar kompetensinya dan memberikan pelayanan kesehatan sesuai standar pelayanan medik, selain itu adanya sistem jejaring guna menata sistem rujukan pada Fasilitas Kesehatan Tingkat Rujukan Lanjutan.

Praktik Mandiri Bidan mengatakan bahwa jumlah klaim yang didapat sesuai dengan jumlah klaim yang diajukan kepada BPJS Kesehatan, namun apabila terjadi keterlambatan penggantian klaim, tidak pernah ada pemberitahuan dari BPJS Kesehatan sehingga PMB hanya bisa menunggu hingga penggantian klaim diberian karena ketika mengalami keterlambatan mereka tidak tahu harus mencari informasi kepada siapa. Sedangkan penggantian tarif klaim mengenai pelayanan yang diberikan kepada pasien JKN merupakan penggantian biaya jasa medis yang diberikan oleh PMB, selain faktor dari BPJS Kesehatan, keterlambatan penggantian klaim juga berasal dari jejaringnya. Pihak jejaring tidak segera mengajukan berkas klaim PMB karena harus menunggu klaim jejaringnya selesai.

Rekan kerja merupakan seseorang yang bekerja bersama, terutama seseorang yang memiliki pekerjaan yang sama atau proyek yang sama. Rekan kerja yang menyenangkan serta kompeten berpengaruh pada kepuasan pekerja (Spector dalam Kusuma , 2016). Faktor rekan kerja yang diteliti dalam penelitian ini adalah hubungan antara bidan dengan jejaringnya. Hasil penelitian menunjukkan bahwa sebagian besar $(75 \%)$ bidan tidak pernah mendapatkan motivasi dari jejaringnya, meskipun demikian, bidan nyaman dan tidak pernah merasa dipersulit maupun mengalami perselisihan dengan jejaringnya. Salah satu faktor yang kondusif untuk meningkatkan kepuasan kerja yang tinggi dengan adanya rekan kerja yang suportif dimana dengan bekerja seseorang dapat mengisi kebutuhan mereka untuk berinteraksi sosial. Oleh karena itu seseorang yang memiliki rekan kerja suportif dan bersahabat dapat meningkatkan kepuasan kerja mereka.

Hasil penelitian mengenai hubungan antara bidan dengan jejaringnya ini mendukung pernyataan dari Kusuma (2016) mengenai faktor-faktor yang mempengaruhi kepuasan kerja diantaranya adalah aspek sosial dalam pekerjaan dan komunikasi. Selain itu juga kepuasan kerja yang tinggi diantara anggota kelompok adalah jika mereka diletakkan kedalam jalinan komunikasi yang erat.

Komunikasi merupakan suatu proses pencapaian informasi berupa pesan, ide, gagasan dari satu pihakke pihak lain. Informasi dalam organisasi dapat dalam bentuk verbal maupun nonverbal (Spector dalam Kusuma, 2016). Faktor komunikasi yang diteliti dalam penelitian ini adalah komunikasi antara bidan dengan jejaringnya. Hasil penelitian menunjukkan bahwa sebagian besar (75\%) bidan rutin berkomunikasi dengan jejaringnya baik secara langsung maupun tidak langsung, meskipun rutin berkomunikasi bidan tidak mengetahui informasi terbaru mengenai JKN. Padahal salah satu cara PMB mengetahui informasi terkait JKN hanya melalui sosialisasi dan informasi dari jejaringnya, hanya saja kedua hal ini tidak berjalan semestinya.

Komunikasi sangat berperan dalam menyosialisasikan program JKN, karena komunikasi merupakan suatu proses kegiatan yang dapat berlangsung secara dinamis. Sesuatu yang didefinisikan sebagai proses, berarti unsurunsur yang ada didalamnya bergerak aktif, dinamis dan tidak statis (Zakiah, 2015).

Dalam penelitian Kwenin (2013) diterangkan bahwa sangat direkomendasikan untuk memperbaiki sistem manajemen dan komunikasi internal untuk meningkatkan kepuasan yang berpengaruh pada kinerjanya 
terhadap organisasi. Hal yang sama juga disampaikan oleh Suyasa (2016), komunikasi internal secara parsial berpengaruh positif dan signifikan pada kepuasan kerja. Hasil penelitian ini juga didukung oleh Kusuma (2016) yang menyatakan bahwa faktor-faktor lain yang mempengaruhi tinggi rendahnya kepuasan kerja antara lain kesempatan untuk maju, keamanan, gaji/upah, perusahaan dan manajemen yang baik, pengawasan atau supervisi, faktor intrinsik dari pekerjaan dan komunikasi.

Keadilan merupakan fungsi dari seberapa adil individu diperlakukan di tempat kerja. Kepuasan merupakan hasil dari persepsi orang bahwa perbandingan antara hasil kerja dan inputnya relatif lebih menguntungkan dibandingkan dengan perbandingan antara keluaran dan masukan pekerjaan lainnya (Kreitner \& Kinicki, 2014). Faktor keadilan yang diteliti dalam penelitian ini adalah seberapa adil bidan jejaring diperlakukan oleh jejaringnya. Hasil penelitian menunjukkan bahwa sebagian $(50 \%)$ bidan tidak setuju dengan adanya pemotongan biaya administrasi maksimal $10 \%$ oleh jejaring, meskipun demikian, faktanya tidak ada bidan yang dipotong klaimnya untuk biaya administrasi oleh jejaringnya, selain itu seluruh bidan jejaring $(100 \%)$ merupakan bidan satu-satunya dari jejaringnya, sehingga jejaring selalu merujuk pasien ke jejaring yang sama, kecuali dalam hal kedaruratan.

Berdasarkan teori Equity yang menjelaskan bahwa kepuasan seseorang bergantung pada keadilan suatu pekerjaan, yang mana pekerjaan adalah salah satu bagian dari situasi kerja. Perasaan puas atau tidak puas seseorang karena merasakan adanya suatu keadilan atau tidak atas situasi kerja. Perasaan puas atau tidak puas dapat diperoleh dengan cara membandingkan dirinya dengan orang lain (Meutuah \& Saifuddin, 2015).

\section{PENUTUP}

Faktor individual yang berhubungan dengan kepuasan kerja Praktik Mandiri Bidan era Jaminan Kesehatan Nasional diantaranya nature of work, pencapaian nilai dan motivasi. Sedangkan faktor struktural yang berhubungan dengan kepuasan kerja Praktik Mandiri Bidan era Jaminan Kesehatan Nasional diantaranya supervisi, rekan kerja, komunikasi dan keadilan.

Penelitian ini hanya mencakup Praktik Mandiri Bidan sebagai jejaring Fasilitas Kesehatan Tingkat Pertama, maka saran yang diberikan untuk penelitian selanjutnya agar dilakukan penelitian terkait faktor kepuasan kepada Fasilitas Kesehatan Tingkat Pertama yang lain, seperti Dokter Praktik Perorangan, Klinik Pratama dan Rumah Sakit Tipe D.

\section{DAFTAR PUSTAKA}

Adolfina. 2014. Analisis Keterkaitan antara Kepuasan Kerja, dan Komitmen Organisasi dengan Kinerja Individu. Jurnal EMBA, 2(3): 864-871.

Alshenqeeti, H. 2014. Interviewing as a Data Collection Method: A Critical Review. English Linguistics Research, 3(1): 39-45.

BPJS Kesehatan. 2018. Fasilitas Kesehatan. Jakarta: BPJS Kesehatan.

Čiarnienè, R., Kumpikaitè, V. dan Vienažindienè, M. 2010. Expectations and Job Satisfaction: Theoretical and empirical approach. The 6th International Scientific Conference "Business and Management 2010”. Selected Papers, 6: 978-984.

Green, P. I., Finkel, E. J., Fitzsimons, G. M., dan Gino, F. 2017. The Energizing Nature of Work Engagement: Toward a New NeedBased Theory of Work Motivation. Research in Organizational Behavior, 37: 1-18.

Gumilang, G. S. 2016. Metode Penelitian Kualitatif dalam Bidang Bimbingan dan Konseling. Fokus Konseling, 2(2), 144-159.

Kadek, N., Juniari, E. dan Riana, I. G. 2015. Pengaruh Motivasi Terhadap Kepuasan Kerja dan Kinerja Pegawai Negeri Sipil (PNS) di Sekolah Tinggi Pariwisata Nusa Dua Bali, Fakultas Ekonomi dan Bisnis Universitas Udayana (UNUD). E-Journal Ekonomi Dan Bisnis Universitas Udayana, 11(4): 823-840.

Karambut, C. A. dan Noormijati, E. A. T. 2012. Analisis Pengaruh Kecerdasan Emosional, Stres Kerja dan Kepuasan Kerja terhadap Komitmen Organisasional (Studi pada Perawat Unit Rawat Inap RS Panti Waluya Malang). Jurnal Aplikasi Manajemen, 10(3): 655-668. 
Kemenkes RI. 2013. Peraturan Menteri Kesehatan Republik Indonesia Nomor 71 Tahun 2013 tentang Pelayanan Kesehatan pada Jaminan Kesehatan Nasional. Jakarta: Kemenkes RI.

Kemenkes RI. 2016. Peraturan Menteri Kesehatan Republik Indonesia Nomor 52 Tahun 2016 tentang Standar Tarif Pelayanan Kesehatan dalam Penyelenggaraan Program JKN. Jakarta: Kemenkes RI.

Kreitner, R. dan Kinicki, A. 2014. Perilaku Organisasi. (D. A. Halim, Ed.) (Kesembilan). Jakarta: Salemba Empat.

Kusuma, M. P., Ayun, S. dan Asmita, W. P. 2016. Faktor-Faktor yang Berhubungan dengan Kepuasan Bidan Praktek Mandiri Era Jaminan Kesehatan Nasional di Kota Semarang. JKM E-Journal, 4(4): 70-78.

Kwenin, D. O., Muathe, S. dan Nzulwa, R. 2013. The Influence of Employee Rewards, Human Resource Policies and Job Satisfaction on the Retention of Employees in Vodafone Ghana. European Journal of Business and Management, 5(12): 13-20.

Meutuah, L. D. dan Saifuddin, I. 2015. Analisis Kepuasan Dokter Spesialis terhadap Program Jaminan Kesehatan Nasional (JKN) di Rumah Sakit Umum Daerah Dr. Zainoel Abidin Tahun 2014. Jurnal Kedokteran Syiah Kuala, 15(1): 7-19.

Mukururi, J. N., \& Ngari, J. M. 2014. Influence of Work Life Balance Policies on Employee Job Satisfaction In Kenya's Banking Sector. IOSR Journal Of Humanities And Social Science, 19(3): $102-112$.

Rindyantika, A. dan Safitri, N. 2014. Analisis Kepuasan Kerja Karyawan Berdasarkan Job Satisfaction Survey (Studi pada Karyawan tetap Kantor Pusat PT Airindo Sakti). FISIP UI: $1-6$.

Safarah, S. H., Widjanarko, B. dan Shaluhiyah, Z. 2018. Faktor-Faktor yang Berhubungan dengan Kepuasan Kerja Dokter Spesialis terhadap Pelaksanaan BPJS Kesehatan di Rumah Sakit Panti Wilasa Dr. Cipto. Jurnal Kesehatan Masyarakat (e-Journal), 6(1): 809-818.
Saleem, R., Mahmood, A. dan Mahmood, A. 2010. Effect of Work Motivation on Job Satisfaction in Mobile Telecommunication Service Organizations of Pakistan. International Journal of Business and Management, 5(11): 213-222.

Starman, A. B. 2013. The Case Study as a Type of Qualitative Research. Journal of Contemporary Educational Studies, 1: 28-43.

Suyasa, P. B., Yudiaatmaja, F., dan Yulianthini, N. N. 2016. Pengaruh Kebijakan Kompensasi dan Komunikasi Internal terhadap Kepuasan Kerja Karyawan. E-Journal Bisma Univeristas Pendidikan Ganesha Jurusan Manajemen, 4(1): 19.

Taufiqurrahman, M., Asmaningrum, N., dan Purwandari, R. 2014. Analisis Determinan Karakteristik Individu Tenaga Keperawatan dengan Kepuasan Kerja di Ruang Rawat Inap Rumah Sakit Umum dr . H . Koesnadi Bondowoso. E-Journal Pustaka Kesehatan, 2(3): 507-514.

Tryanto, D. A. dan Indrawati, F. 2017. Analisis Kinerja Petugas Pelayanan Rawat Jalan Puskesmas Ngesrep dengan Metode Balanced Scorecard. Higeia Journal of Public Health Research and Development, 1(2): 1-10.

Tumewu, E. L., Lumanauw, B. dan Ogi, I. 2014. Karakteristik Individu, Karakteristik Pekerjaan, dan Karakteristik Organisasi terhadap Kepuasan Kerja Karyawan pada Event Organizer Reborn Creative Center Manado. Jurnal EMBA, 2(1): 532-542.

Yandrizal, Anita, B. dan Suryani, D. 2013. Analisis Kebijakan Jaminan Kesehatan Kota Bengkulu dalam Upaya Efisiensi dan Efektifitas Pelayanan di Puskesmas. Jurnal Kebijakan Kesehatan Indonesia, 2(2): 151-160.

Zakiah, S. 2015. Faktor Individual dan Faktor Struktural yang Berperan dalam Keikutsertaan Bidan Praktek Mandiri pada Program Jaminan Kesehatan Nasional di Kabupaten Tabanan. Tesis, Denpasar: Universitas Udayana. 